\title{
POLITOLOGIJA
}

\section{ARTŪRO ZUOKO VIETA LIETUVOS POLITINĖS KONKURENCIJOS LAUKE: SOCIOLOGINÉ ANALIZĖ}

Dr. MaŽVYdAS JASTRAMSKIS

Vilniaus universiteto Tarptautiniu santykių ir politikos mokslu institutas

The Institute of International Relations and Political Science of Vilnius University Vokiečiu g. 10, LT-01130 Vilnius

El.paštas mazvydas.jastramskis@gmail.com

\section{Santrauka}

Lietuvos viešojoje erdvejje dažnai diskutuojama apie rinkejju elgesi, tačiau konkrečiu partiju ar tuo labiau politiku elektoratams skirtu akademiniu straipsniu, kuriuose būtų taikoma kiekybinè analizé, trūksta. $2015 \mathrm{~m}$. kovo mèn. vykusiu pirmuju tiesioginiu mero rinkimu ir buvusio ilgamečio Vilniaus mero Artūro Zuoko pralaimèjimo kontekstas suteikia puikia proga išanalizuoti šio politiko socialine paramos bazę. Pagal tris skirtingus (potencialaus) elektorato analizés lygmenis (objektyvu individo, subjektyvu individo, balsavimo rezultatu teritorinèse rinkimu apylinkèse), analizuojant reprezentatyvius duomenis ir pritaikant statistinius metodus, straipsnyje siekiama nustatyti politiko A. Zuoko vietą nacionalinès politinès konkurencijos lauke. Analize leidžia daryti išvadą, kad buvusio Vilniaus mero sociologinis profilis yra centro dešinysis, artimas liberalams ir konservatoriams.

Reikšminiai žodžiai: Artūras Zuokas; elektoratas; politinès konkurencijos laukas; apylinké; Vilnius; savivaldos rinkimai 2015. 


\section{Ivadas}

Lietuvos politikos mokslų lauke trūksta darbų, skirtų konkrečių partijų ar politikų sociologinei-empirinei analizei. Viena vertus, tai lemia duomenų trūkumas, nes reprezentatyvios apklausos, tiriančios visuomenès nuostatas politikų atžvilgiu, akademiniais tikslais daromos gana retai $^{1}$. Kita vertus, mūsų politinei sociologijai dar tik besivejant Vakarus pagal metodinị pasirengimą, didelè dalis prieinamos, Vyriausiosios rinkimų komisijos (VRK) pateikiamos informacijos apie rinkimų rezultatus lieka nepanaudota. Tai lemia situaciją, kai diskusijos viešojoje erdveje yra menkai paremtos tyrimais ir empiriškai nepagrịstos, o apie politinio subjekto vietą konkurencijos lauke dažnai tiesiog spèliojama (pavyzdžiui, nepaisant A. Zuoko karjeros liberalų partijose, galima rasti ịvairiu nuomonių, kad jis yra populistas, kalbama apie jo balsų atitekimą socialdemokratų kandidatui ir t. t.) $)^{2}$. Todèl šio straipsnio tikslas yra dvejopas - siekiama išsiaiškinti A. Zuoko vietą politiniame Lietuvos lauke pagal jo sociologinę-rinkimų bazę (koncentruojantis $\mathfrak{i}$ tai, kas ji gerai vertina ir už jị balsuoja) ir kartu norima paskatinti empirinès partijų ir politikų analizès raidą mūsiškèje politologijoje.

Kodèl būtent Artūras Zuokas? Pagrindinių Lietuvos partijų konkurencija, jų ideologijos, elektorato bruožai yra nagrinèti daugelio au-

1 Pirmą kartą nacionalinė rinkimų studija, besiremianti išsamia reprezentatyvia apklausa, buvo atlikta 2012-2014 metais. Plačiau žr.: Ramonaitè, A. Ivvadas. Kaip renkasi Lietuvos rinkejjai?: idẻjos, interesai ir ịvaizdžiai politikoje. Mokslinè redaktore A. Ramonaitè. Vilnius: Vilniaus universiteto leidykla, 2014, p. 9-25.

2 Pavyzdžiai iš žiniasklaidos: Račas, A. Zuokiškai gražuliška demokratija. 15min.lt, 201204 15. Prieiga per internetą: <http://www.15min.lt/naujiena/ aktualu/komentarai/arturas-racas-zuokiskai-grazuliska-demokratija-500-210666> [žiūrèta 2015 m. sausio 25 d.]; BNS, ELTA. Politologai vardija kandidatų klaidas. Delfi.lt, 201405 12. Prieiga per internetą: <http://www.delfi.lt/news/daily/lithuania/ politologai-vardija-kandidatu-klaidas.d?id=64764807> [žiūrèta $2015 \mathrm{~m}$. sausio 25 d.]. 
torių darbuose, taip pat ir taikant sisteminị mokslinị metodą ${ }^{3}$. Mažiau dèmesio mūsų politinèje sociologijoje skirta regioninèms jẻgoms, tarp kurių ganètinai stipriai išsiskiria A. Zuokas, $2011 \mathrm{~m}$. su nauju sąrašu Vilniuje sugebejjęs ịveikti visas parlamentines partijas. Nagrinèti jo, kaip lyderio, asmenybės bruožai ${ }^{4}$, fragmentiškai buvęs sostinės meras paminètas nagrinėjant skandalus ${ }^{5}$, partijų programų pristatymus televizijoje $^{6}$, radikaliosios dešinès ${ }^{7}$ problematiką. Tačiau apie dabartinès Lietuvos laisvès sąjungos (liberalų) vadovo sociologinę paramos bazę akademinių tyrimų neturime, nors fenomenas itin įdomus: tai nacionaliniu lygmeniu ne itin mėgstamas (sprendžiant pagal $2014 \mathrm{~m}$. Prezidento rinkimų rezultatus), tačiau sostinèje, ypač savivaldos rinkimuose, gana daug balsų renkantis politikas. Galiausiai, nèra geresnio meto tyrimui apie buvusị Vilniaus vadovą negu po pirmųjų tiesioginių mero rinkimų, kuriuos A. Zuokas pralaimėjo, bet užsiminė apie sugrižimą ị nacionalinę politikąa .

Siekiant nustatyti A. Zuoko ir jo vadovaujamų politinių jègų (iš pradžių „Taip“, dabar LLS (liberalai) vietą Lietuvos politinès konkurencijos lauke sociologiniu požiūriu, straipsnyje igyvendinami trys pagrindi-

3 Lietuvos politinés partijos ir partine sistema. Sudarè A. Jankauskas, E. Kūris, J. Novagrockienè. Kaunas: Naujasis lankas, 1997; Lietuva po Seimo rinkimu 2000. Sudare A. Jankauskas. Kaunas: Naujasis lankas, 2001; Ramonaite, A. Posovietinès Lietuvos politiné anatomija. Vilnius: Versus Aureaus, 2007; Ramonaitè, A. Partinés demokratijos pabaiga? Politinis atstovavimas ir ideologijos. Vilnius: Versus Aureus, 2009; Kaip renkasi Lietuvos rinkejai?: idejos, interesai ir ìvaizdžiai politikoje. Mokslinè redaktorè A. Ramonaitè. Vilnius: Vilniaus universiteto leidykla, 2014.

4 Kavaliauskaite, J. The secret of political leaders' personal appeal: (how) do personality traits matter? Baltic journal of political science. 2014, no. 3, p. 113-133.

5 Palidauskaite, J. Ethical problems in public life and their solution: Lithuanian scenario. Socialiniai mokslai. 2011, Nr. 1, p. 15-23.

6 Smetonienè, I. Politikų diskursas retoriniu aspektu: pristatymo žanras. Parlamento studijos. 2013, Nr. 14 (2013), p. 136-154.

7 Zaremba, A. Ar egzistuoja radikali dešinè Lietuvoje? Politologija. 2013, Nr. 3, p. 46-77.

8 Fuks, E. A. Zuokas Vilniuje deda tašką. Delfi.lt, 201503 15. Prieiga per internetą: $<$ http://www.delfi.lt/news/daily/lithuania/a-zuokas-vilniuje-dedataska.d?id=67435986> [žiūrèta $2015 \mathrm{~m}$. kovo $16 \mathrm{~d}$.]. 
niai uždaviniai. Visų pirma, remiantis moksline literatūra apie Lietuvos partijas ir rinkejjus, išskiriamos pagrindinès šalies politinès takoskyros, elektorato segmentai ir išgryninami tie konkurencijos aspektai, kurie teoriškai turètų būti aktualūs A. Zuokui. Antra, remiantis projekto „Lietuvos nacionalinè rinkiminè studija“ metu atliktos išsamios rinkèjų apklausos duomenimis, išnagrinejjami individo lygmens duomenys - nustatoma, kokios visuomenès grupés geriau vertina A. Zuoką, kas potencialiai sudaro jo elektoratą, kaip ši politiką mégstantys rinkèjai persipina su kitų partijų rèmėjais. Trečia, pagal 2011 ir 2015 m. savivaldos rinkimų Vilniuje rezultatų apylinkèse analizę nustatoma A. Zuoko (ir jo sąrašų) vieta sostinès politiniame lauke. Pagrindiniai straipsnyje naudojami metodai - koreliacijos matai, vidurkių patikimumo intervalai ir daugiamačių skalių analizè.

\section{Esminiai Lietuvos elektorato pjūviai ir partijų konkurencija}

Nepaisant to, kad trūksta akademinių žinių apie A. Zuoko elektoratą, galima nubrèžti tam tikras gaires, prie kokių politinių kategorijų ji priskirti. Šis politikas karjerą pradejo ir nacionaliniu lygmeniu tapo žinomas liberalų partijose, tai liudija dešiniąsias ištakas. Vertinant koalicinị elgesị, A. Zuoko vadovaujama Liberalų ir centro sąjunga (LICS) buvo valdančiosiose daugumose su socialdemokratais (2006-2008) ir konservatoriais (2008-2012 m., A. Zuokas iš partijos išèjo 2010 m.) ${ }^{9}$ politinio centrizmo požymis. Galiausiai, vertinant politikų deklaruojamas pažiūras pagal Manobalsas.lt klausimyną, A. Zuokas ir kiti jo sąrašo politikai turèjo gana centristines, tačiau liberalams ir konserva-

9 Jastramskis, M. Rinkëju elgsenos kaitumas Lietuvos savivaldybių tarybu rinkimuose 1995-2011 metais: daktaro disertacija. Vilniaus universitetas. Vilnius, 2013; A. Zuokas palieka Liberalų ir centro sajungą. Kauno diena, 201006 17. Prieiga per internetą: $<$ http://kauno.diena.lt/naujienos/salies-pulsas/azuokas-palieka-liberalu-ircentro-sajunga-224578\#.VQ_rcPmUeFE> [žiūrèta 2015 m. kovo 2 d.]. 
toriams, palyginti su kitomis partijomis, artimesnes pozicijas ${ }^{10}$.

Natūralu, kad A. Zuoko priskyrimas centrui arba dešinei, bet ne kairei, yra labiau paplitęs. Pavyzdžiui, nagrinėdami geografinị rinkimų rezultatų pasiskirstymą Vilniuje (miesto „elektorinę struktūrą“), Ieva Savickaitè, Dovilè Krupickaitė ir Rolandas Tučas buvusio Vilniaus mero koaliciją priskiria centro dešinei ${ }^{11}$. Tyrèjo intuicija dažnai būna teisinga, be to, logiška tikètis, kad rinkèjai atitiktų savo remiamų politikų vertybes ar požiūrị i galimas koalicijas. Tačiau atsižvelgiant ị mažą Lietuvos rinkejjų ideologinị nuoseklumą, ypač kai lyginama su pačiomis partijomis ${ }^{12}$, rinkimų lygmeniu tokios klasifikacijos pagrịstumas nèra garantuotas. Pavyzdžiui, Lietuvos gyventojai Darbo partiją (DP) laiko mažiau kairiąja nei Lietuvos socialdemokratų partiją, nors pagal elektorato struktūrai aktualius vertybinius klausimus DP daugiau kairioji ${ }^{13}$. Todèl verta peržiūrèti A. Zuoko profilị ir patikrinti empiriškai dešinysis jis ar ne.

Kaip atskirti dešinijji politiką ar partiją Lietuvoje? Dažnai kairès ir dešinès turinys yra vertinamas kaip normatyviškai universalus, ką iš dalies patvirtina í partijų pozicijas orientuoti tyrimai ${ }^{14}$. Vis dèlto atsižvelgiant $\mathfrak{j}$ kiekvienos šalies specifiką ir veiksnius, lemiančius partijų preferencijas dèl individų, naivu tikètis, kad visur dominuos tos pačios vertybinès takoskyros. Lietuva yra savitas atvejis, kurị būtų sunku su-

10 Jastramskis, M. Ideologinis Lietuvos partinès sistemos struktūravimas: ar jau turime kairę ir dešinę?: pranešimas Vilniaus universiteto Tarptautinių santykių ir politikos mokslų instituto ir Lietuvos politologų asociacijos metinèje konferencijoje „Lietuva po Seimo rinkimų", Vilnius, $2012 \mathrm{~m}$. lapkričio $16 \mathrm{~d}$.

11 Savickaitè, I., Krupickaitė, D., Tučas, R. Gyventojų rinkiminès elgsenos kaita Vilniaus suburbanizacijos zonoje. Geografijos metraštis. Nr. 46 (2013), p. 72-94.

${ }^{12}$ Kaip renkasi Lietuvos rinkejjai?: idejos, interesai ir j̣vaizdžiai politikoje. Mokslinè redaktorė A. Ramonaitė. Vilnius: Vilniaus universiteto leidykla, 2014.

${ }^{13}$ Ramonaitè, A., Jastramskis, M. Vertybès ir ịsitikinimų struktūros. Kaip renkasi Lietuvos rinkèjai?: idejos, interesai ir ìvaizdžiai politikoje. Mokslinè redaktorè A. Ramonaitè. Vilnius: Vilniaus universiteto leidykla, 2014, p. 126-144.

${ }^{14}$ Ennser, L. The homogeneity of West European party families: the radical right in comparative perspective. Party politics. Vol. 18, no. 4 (2012), p. 151-171. 
lyginti su bet kuria Vakarų šalimi: po Nepriklausomybès atgavimo iki $2000 \mathrm{~m}$. šalies partinę sistemą stipriausiai struktūravo ekskomunistųantikomunistų matmuo, kuris atitiko lietuviškąją kairę ir dešinę ${ }^{15}$. Kai kurie autoriai pastebi, kad ị ši matmeni gana natūraliai ịsikomponuoja ir geopolitinė Rytų (kairè) ir Vakarų (dešinè) orientacija ${ }^{16}$.

Tyrimai rodo, kad nuo $2000 \mathrm{~m}$. takoskyra pradeda silpnèti, atsirandant naujoms partijoms ir perskyrai tarp naujųjų (populistinių) ir senųjų (tradicinių) politinių jègų, o visuomenè pradèjo vis sunkiau atpažinti kairę ir dešinę ${ }^{17}$. Nepaisant to, neatsirado antikomunistinị matmenị pakeitusios takoskyros, nors vilčių ir būta, ypač žvelgiant ị partijų pavadinimus, mažai besiskiriančius nuo Vakarų Europos politinių jẻgų. Po $2012 \mathrm{~m}$. Seimo rinkimų atlikto išsamaus Lietuvos rinkèjų elgsenos tyrimo rezultatai parodè: iš sociodemografinių ir vertybinių veiksnių būtent sovietmečio vertinimas geriausiai diferencijavo rinkèjus pagal jų partines preferencijas. Kiek supaprastinant, partijų pagal rinkejjus žemèlapis toks: kairè - stipresnè sovietmečio nostalgija (DP, „Tvarka ir teisingumas“), centras - neutralus požiūris (Lietuvos socialdemokratų partija), dešinė - labiau neigiamas sovietmečio vertinimas (Tèvynès sąunga-Lietuvos krikščionys demokratai, Lietuvos Respublikos liberalų sąjūdis $)^{18}$.

Tai nereiškia, kad kiti veiksniai (pajamos, užsiėmimas) nèra svarbūs, tačiau jie arba silpnai atskiria partijų rèmèjus, arba aktualūs tik tam tikroms politinèms jègoms. Remiantis sociodemografiniais paaiškinimais, už dešiniuosius (TS-LKD, LRLS) kiek dažniau balsuoja aukš-

15 Ramonaitè, A. Posovietinés Lietuvos politine anatomija. Vilnius: Versus Aureus, 2007.

16 Jurkynas, M. Politinio konflikto kaita ir takoskyros. Lietuva po Seimo rinkimu 2000. Sudarė A. Jankauskas. Kaunas: Naujasis lankas, 2001, p. 23-33.

17 Ramonaite, A. Posovietinés Lietuvos politine anatomija. Vilnius: Versus Aureus, 2007.

18 Ramonaite, A. Socialinès klasės, sovietmečio vertinimas ir naujoji rinkèjų karta. Kaip renkasi Lietuvos rinkejjai?: idejos, interesai ir ịvaizdžiai politikoje. Mokslinè redaktorè A. Ramonaitè. Vilnius: Vilniaus universiteto leidykla, 2014, p. 90-106. 
tąj j išsilavinimą turintys ir didesniuose miestuose gyvenantys žmonès. Kalbant apie vertybių skirtumus, ekonominio lygmens atžvilgiu yra dvi problemos: pirma, lietuvių pažiūros gana nenuoseklios (dauguma norètų ir mažesnių mokesčių, ir didesnio valstybės kišimosi), antra, daugelio atsakymų i klausimus pasiskirstymas asimetriškas kairiųjų pažiūrų atžvilgiu (pastarųjų pažiūrų daugiau). Viena aiškesnẻ tendencija - LRLS rinkèjai kiek daugiau nepritaria valstybès kišimuisi ị laisvąją rinką, negu kitų partijų rèmẻjai. Analizuojant moralines pažiūras, medianinis rinkejjas yra gana konservatyvus, tačiau nebūtinai religingas. Šis aspektas būdingesnis TS-LKD elektoratui, kuris dažniau lankosi bažnyčioje ir akcentuoja religijos svarbą politikoje. LRLS rinkejjai kiek dažniau nepritaria tradicinès šeimos saugojimui ${ }^{19}$.

Kai kurie veiksniai negali būti susieti su kaire ar dešine,pavyzdžiui, gana aiškiai partijas diferencijuoja amžius, tačiau čia yra esminė skirtis tarp naujesnių (DP ir LRLS) ir senesnių politinių jègų (LSDP, TS-LKD). Nepaisant to, amžiaus sąsajas su A. Zuoko vertinimu verta patikrinti, nes šis politikas dažnai siejamas su jaunesniu elektoratu. Andriaus Kubiliaus vyriausybès ir tuometinès opozicijos partijas (LSDP, TT, DP) $2012 \mathrm{~m}$. atliktoje apklausoje neblogai diferencijavo ekonominių tendencijų vertinimas - dešinieji geriau jas vertino valdant A. Kubiliuii ${ }^{20}$. Tai irgi verta patikrinti. Yra ir kitų rinkejjų elgesiui svarbių nepriklausomų kintamųjų (sutariama, kad šiuolaikinis balsavimas yra labai heterogeniškas reiškinys) ${ }^{21}$, tačiau jie nebūtų aktualūs kategorizuojant politiškai - socialinė aplinka, kampanijos ịtaka, kt.

${ }_{19}$ Ramonaitè, A., Jastramskis, M. Vertybès ir įsitikinimų struktūros. Kaip renkasi Lietuvos rinkejjai?: idejjos, interesai ir ịvaizdžiai politikoje. Mokslinè redaktorè A. Ramonaitè. Vilnius: Vilniaus universiteto leidykla, 2014, p. 126-144.

${ }^{20}$ Jastramskis, M. Pralaimèjimas, prilygintas laimëjimui: gero Andriaus Kubiliaus vyriausybės partijų pasirodymo Seimo rinkimuose priežastys. Politologija. 2014, Nr. 1, p. 36-66.

${ }^{21}$ Blumenstiel, J.E., Plischke, T. Changing motivations, time of the voting decision, and short-term volatility - the dynamics of voter heterogeneity. Electoral studies. Vol. 37 (2015), p. 28-40. 
Analizuojant partijų konkurenciją rinkimuose, svarbu ne tik objektyviai atskirti elektorato bruožus, bet ir atskleisti subjektyvias rinkèjų simpatijas politikams: viena vertus, jos parodo emocinį vertinimą, kita vertus, tai gana efektyvus ir paprastas būdas suskirstyti politines jègas $\mathfrak{i}$ tam tikras kategorijas. Rinkimų Vakaruose tyrimuose partijų simpatijų „termometrai“ naudojami braižant konkurencinę erdvę ${ }^{22}$, bet kartais pritaikomi ir kaip netiesioginiai rodikliai, matuojant potencialų partijos ar kandidato elektoratą ${ }^{23}$. Lietuvoje matyti, kad partijų šalininkų simpatijos ir antipatijos kitoms politinèms jègoms yra veikiamos esamų koalicijų, perskyrų parlamente sudèties. Pavyzdžiui, 2012 m. duomenimis paremtame tyrime 2008-2012 m. opozicijoje buvusias LSDP, TP ir TT buvo itin sunku atskirti vieną nuo kitos, jų vertinimai tarpusavyje stipriai ir teigiamai koreliavo ${ }^{24}$. Vis dèlto pagal tai, kokias partijas ar politikus mejgsta potencialūs A. Zuoko rinkejjai, galètume spręsti, ị kurią politinę pusę jie yra linkę, net jeigu šie vertinimai būtų padiktuoti einamųjų aktualijų.

Tolesnèje straipsnio dalyje bus tikrinamos trys hipotezès. Kiekviena jų remiasi skyriaus pradžioje išdèstytais argumentais, kad A. Zuokas yra daugiau dešinysis politikas, ir tikrina, kiek šis teiginys turi paramos vertinant sociologiškai pagal (potencialų) elektoratą. Trys hipotezès atspindi tris skirtingus būdus patikrinti buvusio sostinès mero vietą politinès konkurencijos lauke: pagal objektyvius elektorato bruožus, subjektyvias simpatijas ir elektorato pasiskirstymą Vilniaus apylinkèse.

1 hipotezè. Pagal savo potencialaus elektorato bruožus A. Zuokas turètų būti artimesnis dešiniosioms (TS-LKD ir LRLS) Lietuvos parti-

${ }^{22}$ Weisberg, H.F., Rusk, J.G. Dimensions of candidate evaluation. The American political science review. Vol. 64(4) (1970), p. 1167-1185.

${ }^{23}$ Rabinowitz, G., MacDonald, S. A directional theory of issue voting. The American political science review. Vol. 83 (1989), p. 93-121.

${ }^{24}$ Ramonaitè, A., Jastramskis, M. Iš ko renkasi rinkèjai? Lietuvos partinès konkurencijos struktūra. Kaip renkasi Lietuvos rinkejjai?:idejos, interesai ir ¿̇vaizdžiai politikoje. Mokslinè redaktorè A. Ramonaitė. Vilnius: Vilniaus universiteto leidykla, 2014, p. 28-44. 
nès sistemos partijoms negu kitoms reikšmingoms kairiosioms partijoms (LSDP, DP, TT, LLRA ${ }^{25}$ ).

2 hipotezè. Partijų konkurencijos lauke labiau palaikantys A. Zuoką rinkejjai turètų labiau mègti ir kitas dešiniąsias partijas bei politikus.

3 hipotezè. Vilniuje apylinkès, kuriose daugiau mègstančių dešiniuosius (TS-LKD ir LRLS), turètų labiau palaikyti ir A. Zuoką.

\section{Kam patinka A. Zuokas?}

Toliau naudojami kiekybiniai duomenys yra paimti iš reprezentatyvios Lietuvos gyventojų apklausos po $2012 \mathrm{~m}$. rinkimų. Apklausa atlikta (užsakovas - VU TSPMI, atlikejjas - „Baltijos tyrimai“) igyvendinant projektą "Lietuvos nacionalinė rinkiminè studija“" (rèmèjas - Lietuvos mokslo taryba, 2012-2014 m., sutarties Nr. MIP-017/2012). I apklausą pakliuvo gana nedaug žmonių - 11 (tai sudaro vos 0,7 procentus visų respondentų), balsavusių už tuometę A. Zuoko partiją „Taip“. Todèl prasmingiau ir kiekybinès analizès atžvilgiu patikimiau naudoti kintamuosius, kurie matuoja, kiek žmonėms patinka A. Zuokas. Tai nėra tikrasis elektoratas, tačiau geresnis vertinimas teoriškai turètų rodyti didesni polinkį kada nors (pavyzdžiui, savivaldybių ar prezidento rinkimuose, kuriuose A. Zuokas rinko gerokai daugiau balsų, nei jo sąrašas $2012 \mathrm{~m}$. Seimo rinkimuose) už ši politinị subjektą balsuoti. Klausimo (analogiški klausimai buvo pateikti ir apie kitų partijų lyderius ir partijas) atsakymų skalè sudare kontinuumą nuo -5 („labai nepatinka“) iki 5 („labai patinka“). Taigi, nulinis taškas reiškẻ neutralų politiko ar partijos ịvertinimą.

${ }^{25}$ LLRA elektoratą analizuoti sunku dèl to, kad jų rinkèjų i apklausas paprastai patenka gana nedaug. Tačiau partijos ir lyderio Valdemaro Tomaševskio pažiūros leidžia šią partiją klasifikuoti kaip kairiąą: žr. Jastramskis, M. Ideologinis Lietuvos partinès sistemos struktūravimas: ar jau turime kairę ir dešinę?: pranešimas Vilniaus universiteto Tarptautinių santykių ir politikos mokslų instituto ir Lietuvos politologų asociacijos metinejje konferencijoje ,Lietuva po Seimo rinkimų“, Vilnius, $2012 \mathrm{~m}$. lapkričio $16 \mathrm{~d}$. 
1 paveikslèlyje pateikiami A. Zuoko ir penkių pagrindinių Lietuvos partijų vertinimo vidurkiai su patikimumo intervalais trijose žmonių kategorijose: pirma, tarp tų, kurie mano, jog sovietmečiu buvo geriau gyventi (kairè), antra - tų, kurie laikosi neutralios pozicijos (centristai), ir, trečia - tų, kurie nemano, jog sovietmečiu buvo geriau (dešinè). Galima pastebèti, kad bendras politikų vertinimas skiriasi: pavyzdžiui, A. Kubiliaus nemėgsta visų kategorijų respondentai, išskyrus gana neutraliai vertinančius antikomunistus, o Algirdas Butkevičius visų grupių žmonių vertinamas teigiamai. Vis dèlto nustatant politikų ir sovietmečio vertinimų ryši, tarp viršutinès ir apatinès paveikslèlių eilutės matosi esminis skirtumas: 2008-2012 m. kadencijos opozicijos lyderius Rolandą Paksą, A. Butkevičių ir Viktorą Uspaskichą respondentai vertina tuo palankiau, kuo geresnè jų nuomonė apie sovietmetị. O štai kalbant apie A. Zuoką, A. Kubilių ir Eligijų Masiulį, tendencija yra atvirkščia: šie politikai vertinami tuo geriau (arba, Zuoko atveju - tiesiog mažiau blogai), kuo blogiau vertinamas sovietmetis. Visi skirtumai statistiškai reikšmingi. Vadinasi, bent jau pagal šị kriterijų A. Zuokas akivaizdžiai yra daugiau dešinysis politikas.

O kaip dèl kitų sociodemografinių ir vertybinių veiksnių, kurie irgi daro poveikį rinkejjų balsavimui? 2 paveikslèlyje pavaizduota, kaip A. Zuoko vertinimą veikia pirmajame skyriuje išskirti veiksniai, svarbūs atskiriant dešinès pakraipos elektoratą Lietuvoje: išsilavinimas, gyvenamoji vieta, bažnyčios lankymas (kaip religingumo indikatorius), ekonominis liberalizmas (kaip nepritarimas nelygybės mažinimui turtingujų sąskaita), ekonominių tendencijų A. Kubiliaus vyriausybės valdymo metu vertinimas. Matyti šie svarbiausi dalykai: A. Zuoką geriau (ne taip blogai) vertina žmonės, kurie turi aukštąji išsilavinimą (viršutinis kairysis paveikslèlis), gyvena didmiesčiuose (viršus, dešinė), mano, kad ekonomika per paskutinius A. Kubiliaus vyriausybès valdymo metus nepasikeitė arba pagerèjo (apačia, kairè). Kiti kintamieji veikia silpniau, jų ịtaka nèra statistiškai reikšminga. 

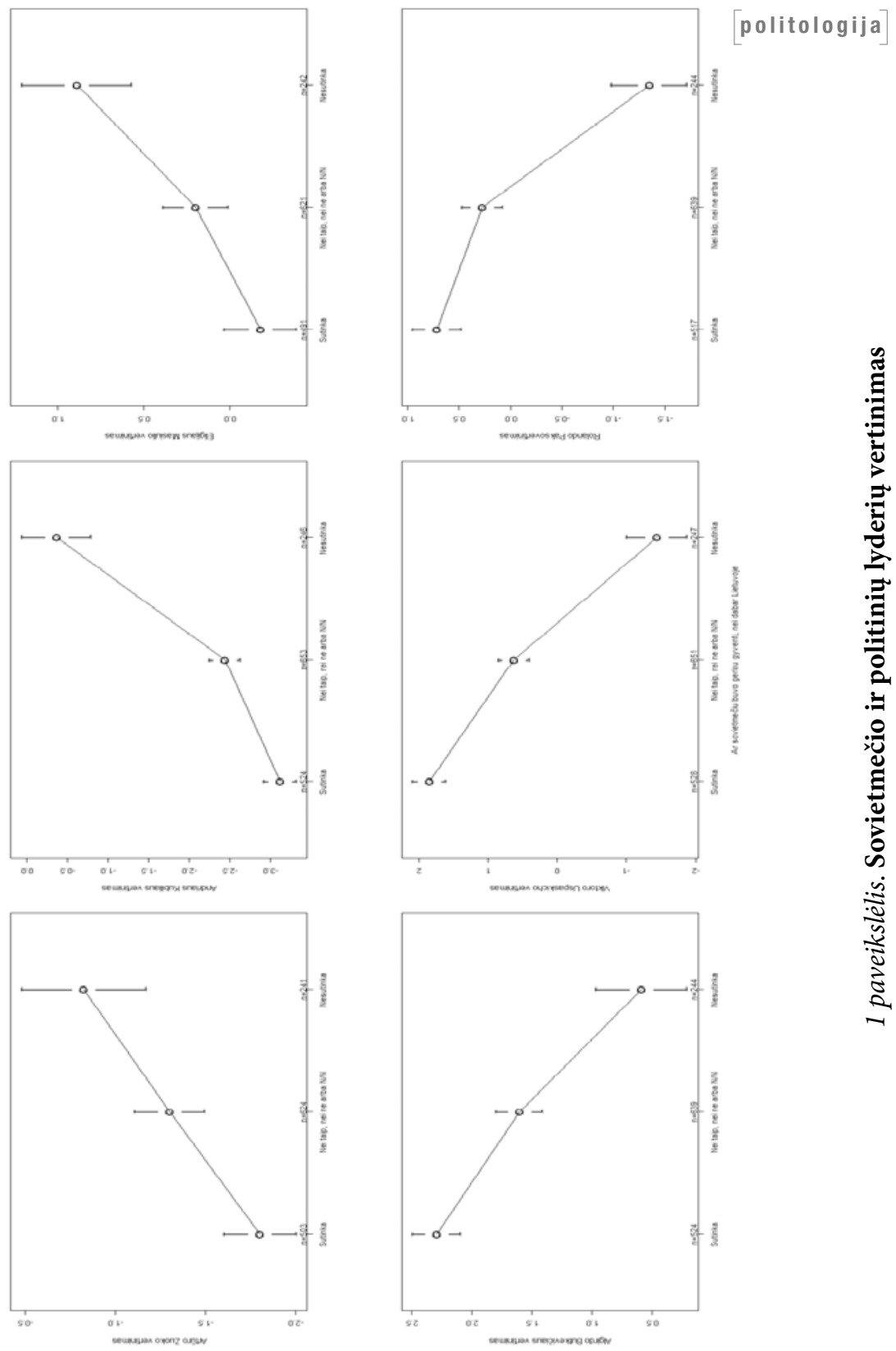

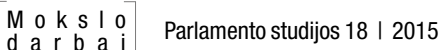


politologija]
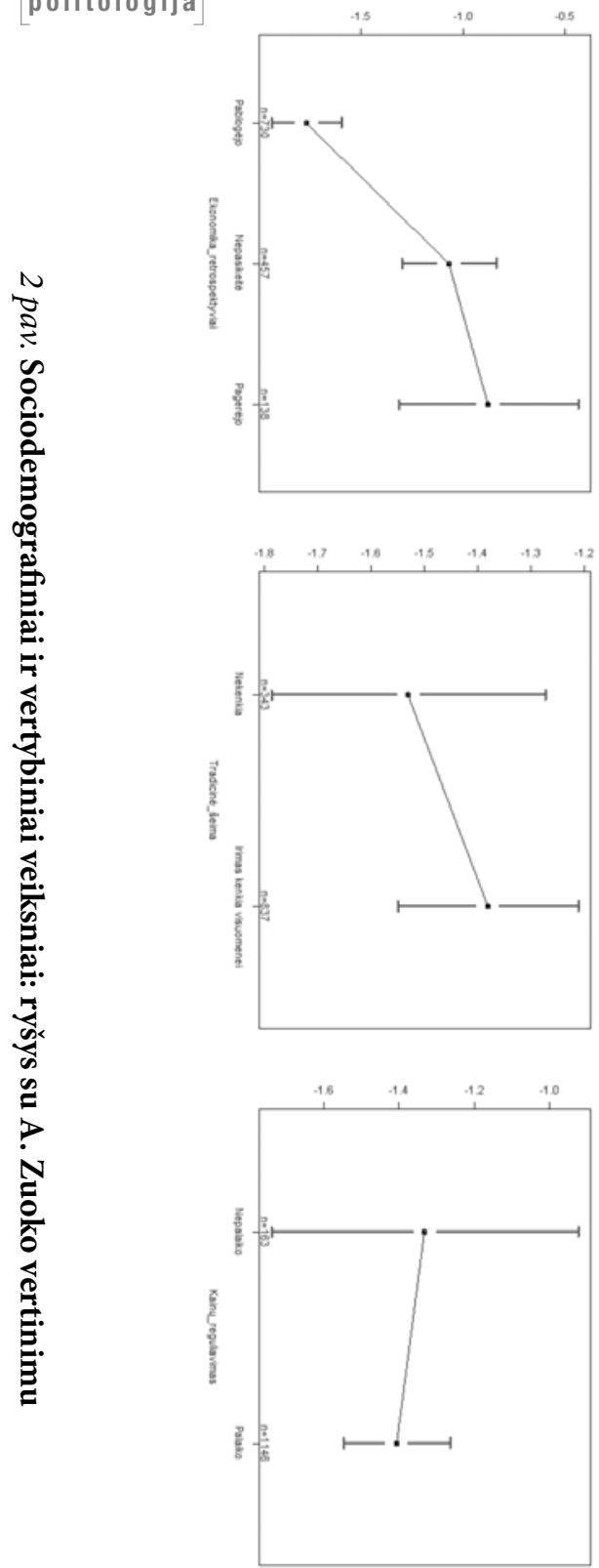
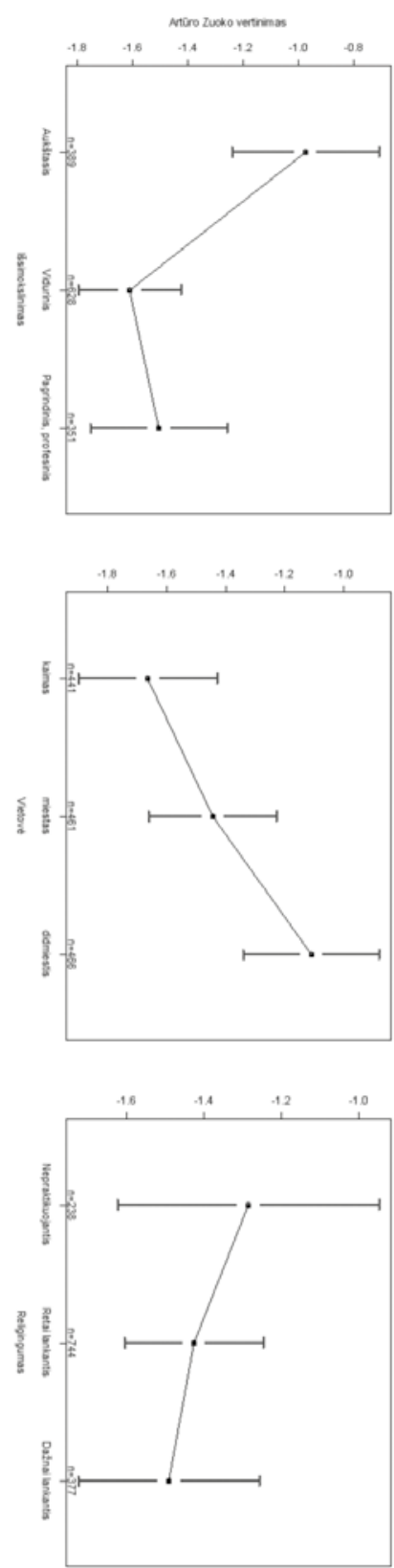

Parlamento studijos 18 | $2015\left[\begin{array}{llllll}M & 0 & k & s & \text { l } & 0 \\ d & a & r & b & a & i\end{array}\right]$ 
Galiausiai, verta patikrinti kairès-dešinès perskyrai mažiau aktualų, bet bendrai sociologiniam A. Zuoko profiliui svarbų veiksni - amžių. 3 paveikslèlyje pavaizduotas A. Zuoko vertinimų tankumas trijose stambiose amžiaus kategorijose, linijos aukštis rodo atitinkamų vertinimų (pavyzdžiui, „-1“) paplitimą konkrečioje amžiaus kategorijoje (pavyzdžiui, jų pasitaikè 10 procentų, tai vertikalaus stulpelio žyma yra „0,1“). Apskritai visose grupèse A. Zuoko vertinimai yra asimetriški, gerų (nuo nulio ị teigiamą pusę) gerokai mažiau. Tačiau jauniausiujų pasiskirstymas pasislinkęs daugiau ị dešinę, būtent ị teigiamą pusę, ir jų vidurkis yra didžiausias. ANOVA ir post hoc kriterijų testai rodo, kad tai yra statistiškai reikšmingas skirtumas - kitaip tariant, jaunesnieji buvusị Vilniaus merą tikrai vertina šiek tiek geriau. Tai nereiškia, kad nèra didelès dalies ir tarp jaunimo, kurie A. Zuoką vertina prastai. Vis dèlto galima pamatyti, kad raudonos linijos (18-29 metai) tankumas yra simetriškesnis nei kitų dviejų amžiaus grupių.

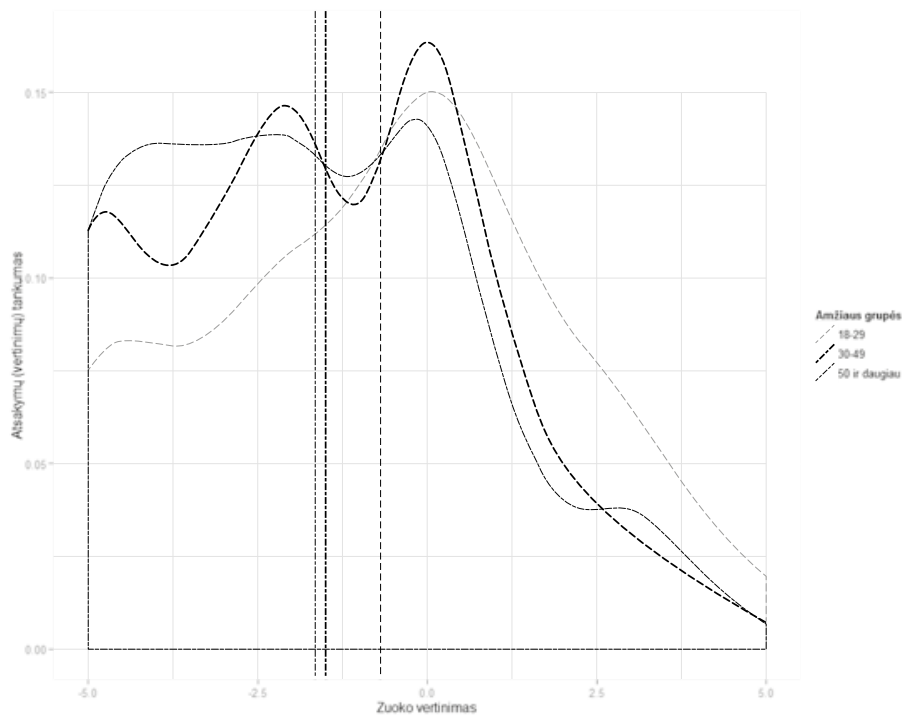

3 pav. Trys amžiaus grupès ir A. Zuoko vertinimo tankumo diagrama 
Apibendrinant A. Zuoko sociologinị profili pagal pagrindinius rinkejjų elgseną Lietuvoje paaiškinančius sociodemografinius ir vertybinius veiksnius, išaiškejja įdomus paveikslas, kuris suteikia paramos pirmajai hiptozei. Buvusị Vilniaus merą labiau palaikantys rinkèjai yra išsilavinę, gyvena didmiesčiuose, neigiamai žiūri ị sovietmetị, neutraliai ar gerai vertina Lietuvos ekonomiką paskutiniaisiais centro dešinès koalicijos valdymo metais. Be to, palaikyti A. Zuoką daugiau linkę jaunesnio amžiaus gyventojai. Kita vertus, sunku ką nors pasakyti apie A. Zuoko profili pagal klasikinius politinius vertybinius matmenis, nes skirtumai tarp atskirų grupių yra menki. To šaltiniai, tikètina, yra du: pirma, bendrai maža rinkejjų diferencijacija pagal ideologinius skirtumus ir, antra, paties mero dviprasmiškos pozicijos.

Objektyvus elektorato „pjaustymas“ it kategorijas pateikia tik dalini vaizdą: A. Zuoką labiau palaikantys panašesni į LRLS ir TS-LKD rinkejjus, tačiau šios partijos gali ir nepatikti. 1 lentelèje pateikiamos koreliacijos tarp politinių jègų vertinimų po $2012 \mathrm{~m}$. Seimo rinkimų. Pirmosios eilutès atskleidžia ryšius tarp sąrašo „Taip“ ir kitų partijų vertinimo, o apatinès dvi - tarp A. Zuoko ir penkių pagrindinių partijų lyderių vertinimo. Kadangi kintamieji matuoti rangine skale, pritaikytas Spearmano ranginès koreliacijos metodas. Žvaigždutès nurodo statistiškai reikšmingas $(\mathrm{p}<0,05)$ koreliacijas.

1 lentelè. A. Zuoko ir jo sąrašo „Taip“ bei kitų politinių jègų vertinimų koreliacijos po 2012 m. rinkimų

\begin{tabular}{|c|c|c|c|c|c|}
\hline & TS-LKD & LRLS & LSDP & DP & TT \\
\hline „Taip“ & $0,30^{\star}$ & $0,29^{\star}$ & $-0,02$ & 0,03 & $0,07^{\star}$ \\
\hline & A. Kubilius & E. Masiulis & $\begin{array}{c}\text { A. Butke- } \\
\text { vičius }\end{array}$ & $\begin{array}{c}\text { V. Uspaski- } \\
\text { chas }\end{array}$ & R. Paksas \\
\hline A. Zuokas & $0,30^{\star}$ & $0,28^{\star}$ & $-0,02^{\star}$ & $0,07^{\star}$ & $0,12^{\star}$ \\
\hline
\end{tabular}

Iš pateiktų rezultatų matyti, kad šiek tiek stipresnès koreliacijos fiksuotos tarp „Taip“ ir TS-LKD, „Taip“ ir LRLS, A. Zuoko ir A. Kubiliaus, 
A. Zuoko ir E. Masiulio. Kaip matyti iš grafinio šių ryšių atvaizdavimo 4 paveikslèlyje (kiekvienas „burbuliukas“ rodo atitinkamos atsakymų kombinacijos tankumą), teigiamos koreliacijos rodo, kad nemėgstantys dešiniųjų daugiau linkę nemėgti ir buvusio Vilniaus mero (jo partijos). E. Masiulio ir LRLS atvejais (dešinè grafiko dalis) kiek daugiau išryškejja ir koncentracija rinkejjų, palaikančių abi politines jègas (tokių atvejų, kad mėgtų A. Zuoką ir nemėgtų LRLS, labai mažai). Kita vertus (1 lentelè), tarp A. Zuoko ir centro kairiųų vertinimų ryšio beveik nerasta: koreliacijos arba statistiškai nereikšmingos, arba labai silpnos. Tai rodo centro dešinijj buvusio Vilniaus mero profili.
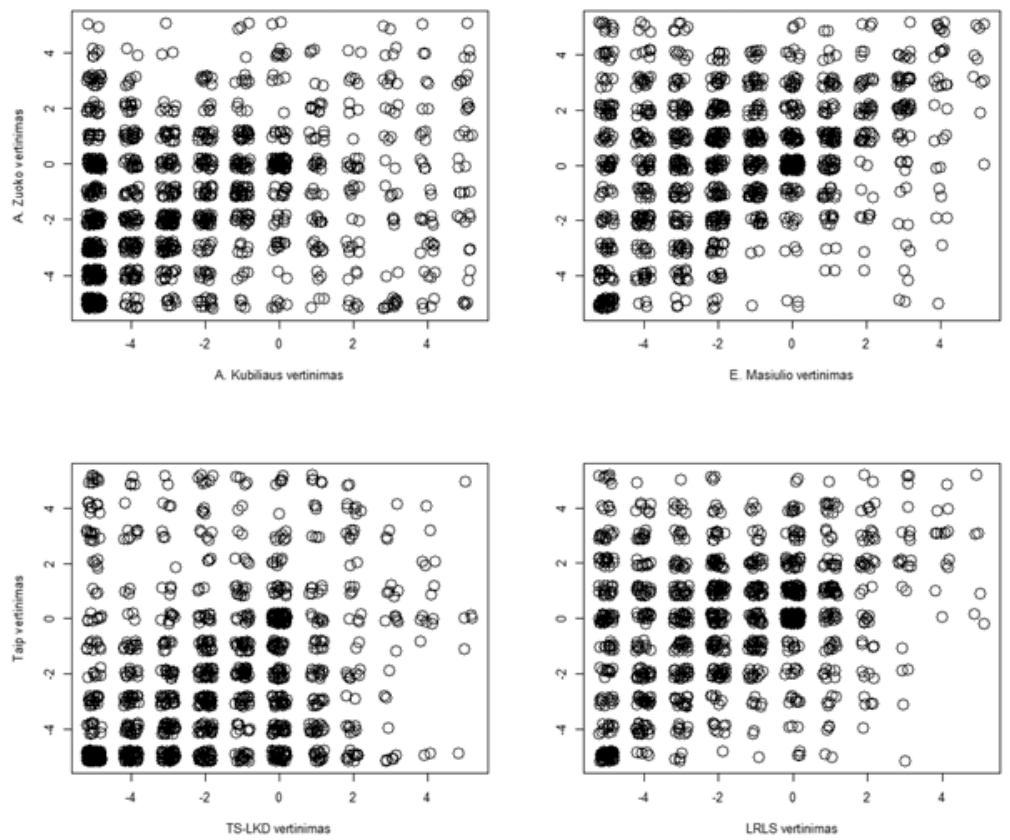

4 pav. A. Zuoko (sąrašo „Taip“) ir dešiniųjų vertinimo koreliacijos grafiškai 
Galiausiai, reikètų ìvertinti politinių jègų konkurenciją, pritaikant vieną apibendrinantị statistinị modelị (kas nèra įmanoma, remiantis tik koreliacijomis ar vidurkių patikimumo grafikais). Toki sprendimą pasiūlo daugiamačių skalių metodas ${ }^{26}$, kuris jau anksčiau lietuviškame kontekste buvo sèkmingai pritaikytas, stebint gyventojų suvokiamą partinès sistemos struktūrą nuo pat 1992 iki $2012 \mathrm{~m} .{ }^{27}$ Skirtingai nei minètame straipsnyje, šị kartą i vieną modelị sudèti svarbiausi partijų lyderiai - kad geriausiai matytųsi jų kategorijos, panaudoti visų partijų lyderių vertinimai, gauti po $2012 \mathrm{~m}$. rinkimų atliktoje apklausoje.

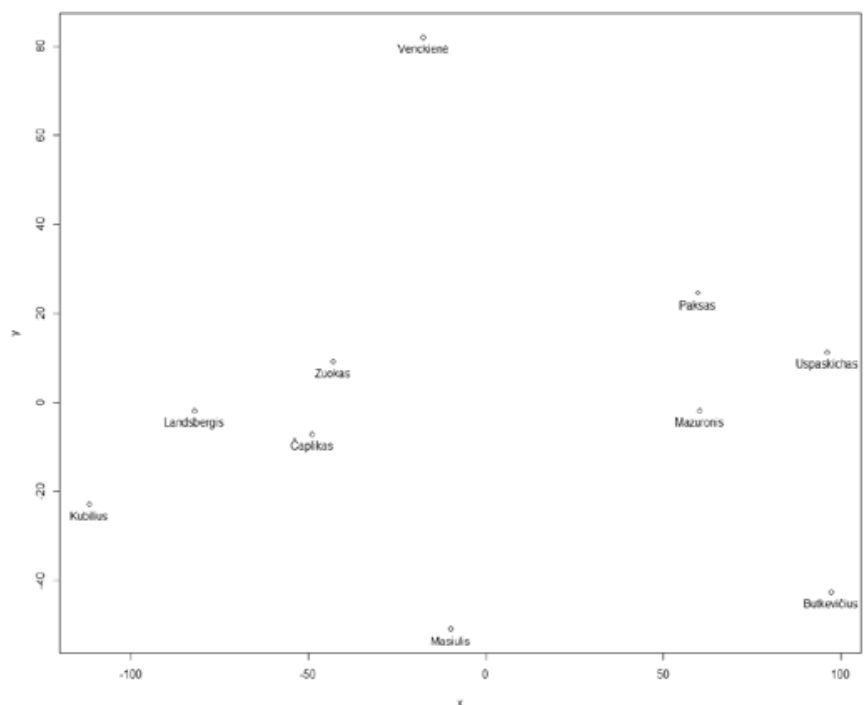

5 pav. Lietuvos politikų konkurencinè erdvė $2012 \mathrm{~m}$.

${ }^{26}$ Weisberg, H.F., Rusk, J.G., Borre, O. The changing party space in Danish voter perceptions, 1971-73. Party identification and beyond: representations of voting and party competition. Edited by I. Budge, I. Crewe, D. Farlie. ECPR Press, 2010, p. 137-162.

${ }^{27}$ Ramonaite, A., Jastramskis, M. Iš ko renkasi rinkejjai? Lietuvos partinès konkurencijos struktūra. Kaip renkasi Lietuvos rinkëjai?: idèjos, interesai ir ịvaizdžiai politikoje. Mokslinè redaktorè A. Ramonaitè. Vilnius: Vilniaus universiteto leidykla, 2014, p. 28-44. 
Daugiamačių skalių analizès grafinis sprendinys pavaizduotas 5 paveikslèlyje. Panašiai kaip ir Lietuvos partijų atveju, gana neblogai atsiskiria kairès ir dešinès poliai (horizontali dimensija), buvusiai „Drąsos kelio“ lyderei Neringai Venkienei sudarant atskirą kategoriją (vertikali dimensija, panaši ị tradicinių ir protesto, naujųjų partijų skirtį), o liberalams, šiuo atveju E. Masiuliui, pasislenkant ị vidurị (taip atsitinka dèl to, kad juos gana neutraliai vertina tiek TS-LKD, tiek kairiųjų rèméjai). Kalbant apie A. Zuoką, jis natūraliai yra artimiausias tuometinès LICS, iš kurios išejo po 2008 m. rinkimų, lyderiui Algiui Čaplikui. Tačiau ir bendrame sprendinyje jo pozicija, nors ir tobulai nesutampa, akivaizdžiai yra gerokai artimesnè dešiniesiems politikams, negu centro kairès lyderiams. Tai suteikia paramos antrajai hipotezei.

\section{Vilniaus konkurencinis laukas savivaldos rinkimuose}

Iki šiol straipsnyje buvo nagrinètas ne tikrasis A. Zuoko ir jo sąrašu elektoratas, o potencialas: žiūrèta, kuo pasižymi geriau (arba tiesiog mažiau blogai) buvusị Vilniaus merą vertinantys žmonės. Šiame skyriuje, panaudojant VRK duomenis apie $2011 \mathrm{~m}$. ir $2015 \mathrm{~m}$. savivaldos rinkimus (abiejuose A. Zuokas dalyvavo su savo sąrašais, o $2015 \mathrm{~m}$. ir atskirai kandidatavo ị merus), tiriama partijų ir kandidatų i merus konkurencija Vilniuje pagal balsavimo rezultatus apylinkèse. Geografų tyrimai rodo, kad politiškai Vilnius yra gana diferencijuotas miestas, jo apylinkių balsavimo tendencijos skiriasi ${ }^{28}$. Taigi, panaudodami statistinius metodus, galime tikètis atskirti panašių (skirtingų) politinių jègų kategorijas pagal balsavimo tendencijas rinkimų apylinkėse.

Patogu pradèti nuo $2011 \mathrm{~m}$. rinkimuose apylinkèse gautų partijų rezultatų. Juose A. Zuoko ir Vilniaus koalicija gavo daugiausia balsų, tačiau tai nebuvo îspūdingas laimejjimas, pirma vieta užimta su vos

${ }^{28}$ Savickaite, I., Krupickaitė, D., Tučas, R. Gyventojų rinkiminès elgsenos kaita Vilniaus suburbanizacijos zonoje. Geografijos metraštis. Nr. 46 (2013), p. 72-94. 
17,7 proc., o ị tarybą pateko 6 partijos. Būtent šių sostinejje politiškai reikšmingų partijų (mažesniųjų balsus dèl nedidelès dispersijos ị statistinę analizę traukti nebuvo verta) balsų koreliacijos (Pearsono koeficientas) pateiktos 2 lenteleje. Sostinèje yra 151 apylinkè, tad imtis kiekybinei analizei pakankamai didelè, o beveik visi gauti koeficientai, išskyrus du (TT su LSDP, TT su Lietuvos lenkų rinkimų akcijos ir Rusų aljanso koalicija), yra statistiškai reikšmingi.

Galima matyti, kad aiškiai atsiskiria dešiniųjų kategorija, i kurią patenka A. Zuoko sąrašas ir TS-LKD. Pirma, šie sąrašai turi labai stiprią teigiamą koreliaciją tarpusavyje (Pearson=0,7) - tos apylinkès, kurios daugiau balsavo už konservatorius, daugiau balsavo ir už A. Zuoko ir Vilniaus koaliciją. Antra, jų abiejų koreliacijos su DP bei LLRA ir RA sąrašais yra stiprios ir neigiamos. Taigi, apylinkès, daugiau rèmusios kairiųjų-etninių mažumų bloką, gerokai mažiau rèmė tiek TS-LKD, tiek A. Zuoką. Centristiškumu pasižymi LSDP, kurios koreliacijos su dešiniaisiais teigiamos, bet silpnesnès nei šių tarpusavyje, tačiau socialdemokratai neturi, išskyrus su LLRA ir RA koalicija, stiprių neigiamų koreliacijų su kitais sąrašais.

2 lentele. Koreliacijos tarp ị Vilniaus savivaldybès tarybą $2011 \mathrm{~m}$. patekusių sąrašų gautų balsų apylinkèse $(\mathrm{N}=151)$

\begin{tabular}{|c|c|c|c|c|c|}
\hline & TS-LKD & LSDP & DP & TT & LLRA ir RA \\
\hline A. Zuoko ir Vilniaus koalicija & 0,7 & 0,28 & $-0,72$ & $-0,26$ & $-0,8$ \\
\hline TS-LKD & & 0,54 & $-0,72$ & $-0,20$ & $-0,76$ \\
\hline LSDP & & & $-0,3$ & 0,13 & $-0,53$ \\
\hline DP & & & & 0,41 & 0,54 \\
\hline TT & & & & & 0,07 \\
\hline
\end{tabular}

Tam, kad Vilniaus konkurencinis laukas išryškètų dar geriau, VRK duomenims (ị sostinès tarybą patekusių partijų balsai apylinkèse vertinami kaip atskiri kintamieji) buvo pritaikytas daugiamačių skalių metodas. Kiek žinoma straipsnio autoriui, apylinkių lygio rinkimų 
rezultatams tokia operacija iki šiol pritaikyta nebuvo. Tiriant atskirų geografinių vienetų politikos konkurencinị lauką daugiamatès skalès gali būti ir naudingas, ir pagrịstas sprendimas. Pirma, apylinkes pagal atiduotus balsus galima vertinti kaip konkrečias partijas ir politikus labiau mėgstančias ar jų nemėgstančias, kaip ir vertinant apklausų duomenis - tik čia jau kalbame apie realius rinkimų rezultatus, o ne politikų ar partijų simpatijas, kurios nebūtinai virsta $\mathfrak{i}$ balsus. Antra, nors tokia analize gautas metodas nebūtinai atspindès tam tikras ideologines dimensijas, jis viename modelyje parodys atstumus tarp partijų, remiantis rinkimų rezultatais skirtingose apylinkèse.

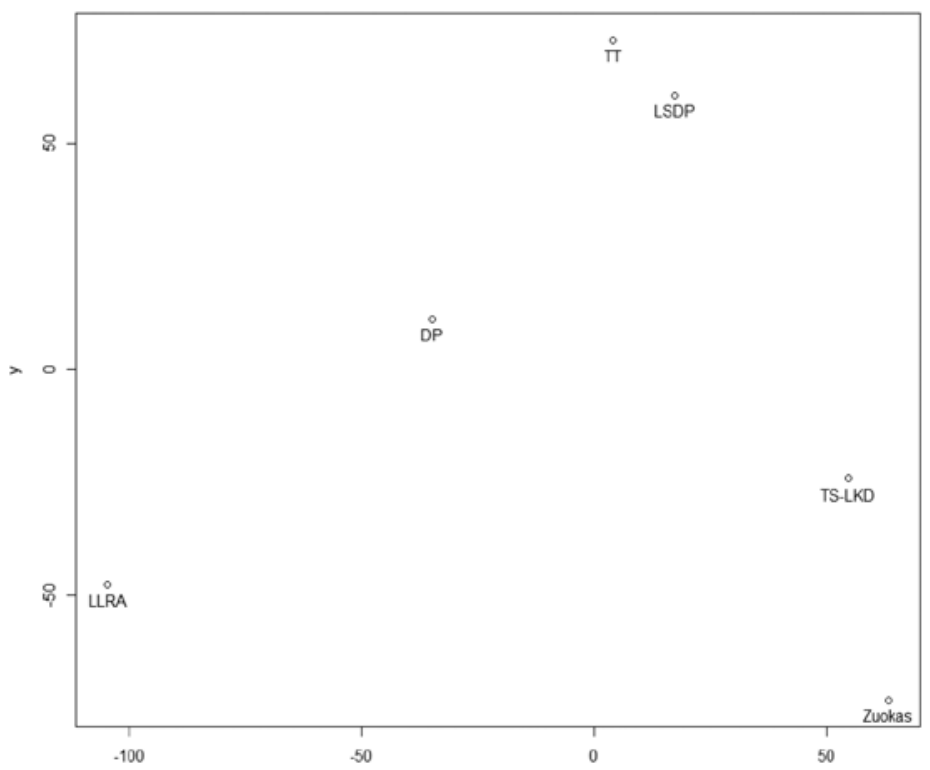

6 pav. Vilniaus savivaldybės konkurencinis laukas $2011 \mathrm{~m}$. rinkimuose 
Pagal 2011 m. rinkimų rezultatus Vilniuje gautas daugiamačių skalių analizės sprendinys grafiškai pavaizduotas 6 paveikslèlyje. Šs rezultatas patvirtina tendencijas, matytas koreliacijų analizejje: A. Zuoko sąrašai ir konservatoriai sudaro vieną atskirą kategoriją ir yra artimesni vienas kitam, negu visoms kitoms partijoms. Panašu, kad vertikali dimensija atskiria apskritai daugiau ir mažiau balsų gavusias partijas - nuo vidurio ị apačią yra pirmieji keturi sąrašai pagal balsus. O štai horizontali dimensija daugiau susijusi su jų ideologiniu profiliu ir apylinkių elektorato struktūra. Nors tam patikrinti neturime duomenų, galima interpretuoti, kad už TS-LKD ir A. Zuoką labiau balsavo didesnes pajamas gaunantys lietuvių tautybès vilniečiai. LLRA su RA koalicija, besitaikanti visų pirma ị lenkų ir rusų tautines mažumas, natūraliai užima nišą pagal tautinị kriterijų. DP, kuri, tikètinai daugiau balsų gavo iš mažiau uždirbančių vilniečių, taip pat ir iš tautinių mažumų, yra per vidurị - panašiai nutolusi nuo tautinị profilị turinčios LLRA, mažiau sèkmingų rinkimuose LSDP ir TT bei dešiniųjų - TS-LKD ir A. Zuoko sąrašo.

3 lentele. Koreliacijos tarp ì Vilniaus savivaldybès tarybą 2015 m. patekusių sąrašų gautų balsų apylinkèse $(\mathrm{N}=\mathbf{1 5 1})$

\begin{tabular}{|c|c|c|c|c|c|c|}
\hline & TS-LKD & LRLS & LS & LSDP & TT & LLRA ir RA \\
\hline LLS (liberalai) & 0,48 & 0,7 & 0,1 & 0,13 & $-0,51$ & $-0,71$ \\
\hline TS-LKD & & 0,59 & 0,32 & 0,43 & $-0,57$ & $-0,84$ \\
\hline LRLS & & & 0,03 & 0,16 & $-0,7$ & $-0,85$ \\
\hline LS & & & & 0,37 & 0,01 & $-0,36$ \\
\hline LSDP & & & & & $-0,33$ & $-0,43$ \\
\hline TT & & & & & & 0,59 \\
\hline
\end{tabular}

Kiek tvarios šios $2011 \mathrm{~m}$. išryškèjusios tendencijos? $2015 \mathrm{~m}$. kontekstas buvo jau kitas - tiesioginiai mero rinkimai, didesnis dèmesys asmenybėms, todèl privaloma analizuoti tiek sąrašų, tiek kandidatų $\mathfrak{i}$ mero postą gautų balsų tarpusavio ryšius. Vis dèlto 
iš 2 lentelès matyti, kad net ị konkurenciją ịsiterpus LRLS, kurie $2011 \mathrm{~m}$. neperžengè 4 proc. barjero, A. Zuoko vadovaujama LLS (liberalai) smarkiai nepakeitè savo profilio ir liko dešiniųjų bloke: visos trys šio bloko partijos (trečia - TS-LKD) tarpusavyje turi stiprias teigiamas koreliacijas. Be to, akivaizdus šių partijų populiarumo pagal apylinkes priešingumas TT, LLRA ir RA sèkmei: ten, kur geriau sekèsi LLS ir kitoms dešiniosioms partijoms, ten silpnesni buvo „tvarkiečiai“ ir Valdemaro Tomaševskio aljansas (tai matyti iš stiprių neigiamų koreliacijų).

Koreliacijų tarp bent tris procentus gavusių kandidatų i merus analizè atskleidžia gana panašius ryšius, todèl verta iš karto pereiti prie grafinio palyginimo. 7 paveikslèlyje lyginami pagal daugiamačių skalių analizę gauti konkurencinio Vilniaus lauko sprendiniai sąrašams (kairèje) ir kandidatams ị merus (dešinèje). Kaip ir 2011 m., vertikali linija abiejuose grafikuose atskiria sèkmingesnes politines jègas nuo gavusių mažiau balsų, o horizontali labiau panašesnè ị pasidalijimus pagal idejjinę kryptị ir rinkẻjus. Jeigu ši interpretacija teisinga, $2015 \mathrm{~m}$. savivaldos rinkimuose esminė konkurencija buvo tarp lietuviškų partijų (dešiniosios abiejų grafikų pusės) ir LLRA su RA (kairiosios abiejų grafikų pusès), tai taip pat gali atspindèti ir geopolitinès orientacijos skirtumus (tiek tarp partijų, tiek tarp rinkèjų). Kairès-dešinès dimensijoje tarp lietuviškų partijų didesnių skirtumų nèra, bet tiek LLS (liberalai), tiek A. Zuokas yra gana artimi dešiniosioms TS-LKD ir LRLS, nors ir kiek pasislinkę ị centrą, palyginti su $2011 \mathrm{~m}$. rinkimais - gana natūralu, turint galvoje LRLS ir šio sąrašo lyderio Remigijaus Šimašiaus sẻkmę. Tai, kad pastarieji du abiejuose sprendiniuose užima gana aiškią ir nuo kitų lietuviškų partijų nutolusią nišą, yra nulemta ne tiek ideologinių skirtumų, kiek aiškaus pirmavimo tiek sąrašų, tiek mero rinkimuose. 

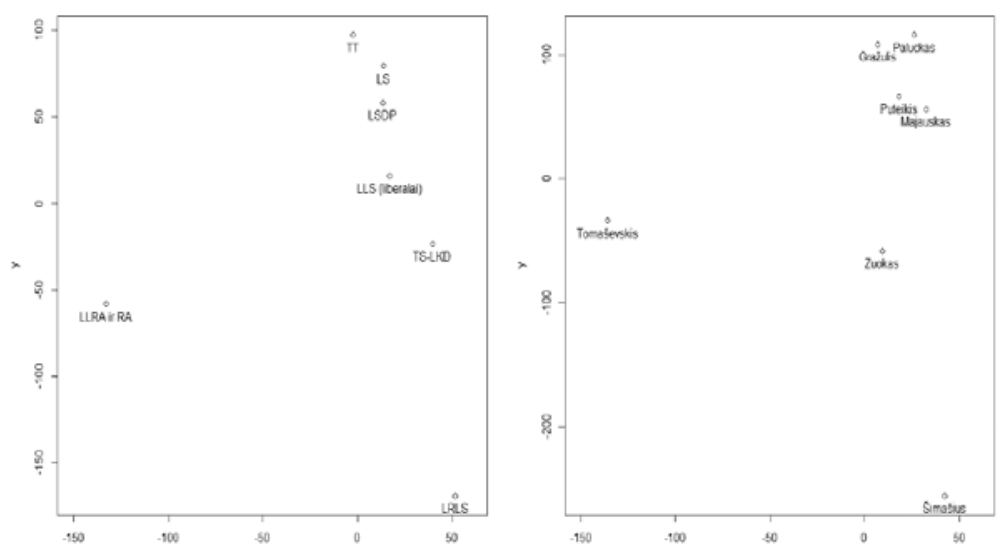

7 pav. Vilniaus savivaldybės konkurencinis laukas 2015 m. rinkimuose

Partijų konkurencijos pirmajame savivaldos rinkimų ture analizè rodo, kad A. Zuoko ir jo vadovaujamos partijos profilis, nors ir kiek pasislinkęs ị centrą, vis dèlto išliko labai tolimas Vilniuje kairès vietą aiškiai užimančiai LLRA ir RA koalicijai. Logiška, kad antrajame tiesioginių mero rinkimų ture likus dviem kandidatams, A. Zuokas būtų buvęs suvoktas kaip artimesnis kairei ir pritrauktų mažiau uždirbančių ir tautinių mažumų balsus. Be to, 2011-2015 m. kadencijos metu sostinès meras atliko ne vieną viešųjų ryšių veiksmą, skirtą praplèsti savo rinkimų bazę orientuojantis būtent ì tautines mažumas - galima paminèti skeptišką požiūrị ỉ krizès Ukrainoje priežastis (dalị kaltès perkeliant ES) ${ }^{29}$,

${ }^{29}$ Bagdžiūnaitè, L. A. Zuokas mano, kad dèl įvykių Ukrainoje kalta ES ir Lietuvos prezidentè. Žinių radijas, 201403 05. Prieiga per internetą: $<$ http://www.ziniuradijas. lt/epizodas/2014/03/05/a-zuokas-mano-kad-del-ivykiu-ukrainoje-kalta-es-irlietuvos-prezidente/30812> [žiūrèta $2015 \mathrm{~m}$. balandžio 29 d.]. 
dalyvavimą geopolitinę potekstę turèjusioje Rusijos dienos šventejje Vilniaus Vingio parke ${ }^{30}$.

8 paveikslèlyje vizualizuojamos koreliacijos tarp, iš vienos pusès, A. Zuoko ir R. Šimašiaus paramos balsų prieaugio (atskirai) ir, iš kitos pusès, trečią ir ketvirtą vietą užèmusių kandidatų balsų pirmajame ture: kairiojo, tautinėms mažumoms atstovaujančio V. Tomaševskio ir dešiniojo, visiškai i lietuvišką elektoratą besiremiančio TS-LKD atstovo. Rezultatai gana įdomūs. Mykolas Majauskas su A. Zuoku turi atvirkščią koreliaciją - kitaip tariant, ten, kur M. Majauskas gavo daugiau, A. Zuoko balsų prieaugis buvo mažesnis. Kita vertus, R. Šimašiaus balsai su M. Majausku iš viso nekoreliuoja (tikètina, taip yra dèl to, kad jau pirmajame ture dalis konservatorių balsavo už LRLS kandidatą). Kalbant apie V. Tomaševskio gautus balsus, R. Šimašiaus balsų prieaugis turi silpną teigiamą koreliaciją (galima pastebėti, kad ryšys nèra visiškai tiesinis), taigi, šiek tiek balsų iš tautinių mažumų liberalas R. Šimašius vis tik gavo. Bet štai A. Zuoko prieaugio koreliacija su LLRA lyderio balsais kone tobula - tai rodo, kad konkurencinèje erdvèje LLRA rèmèjams jis buvo artimesnis negu R. Šimašius. Kita vertus, tai nesumenkina išvados apie A. Zuoką, kaip centro dešiniojo profilio politiką, nes pirmajame ture skirtumai išliko, o antrajame galejo dominuoti balsavimas „priešc.

${ }^{30}$ Grinkevičius, P. Vilniaus Vingio parke - Rusijos diena su Rusijos vèliavomis, o kai kur ir Georgijaus juostelèmis atlapuose. 15min.lt, 201506 08. Prieiga per internetą: <http://www.15min.lt/naujiena/aktualu/lietuva/vilniaus-vingio-parkerusijos-diena-pavieniai-asmenys-su-rusijos-veliavomis-ir-georgijaus-juostelemisatlapuose-56-432253> [žiūrèta $2015 \mathrm{~m}$. kovo 23 d.]. 

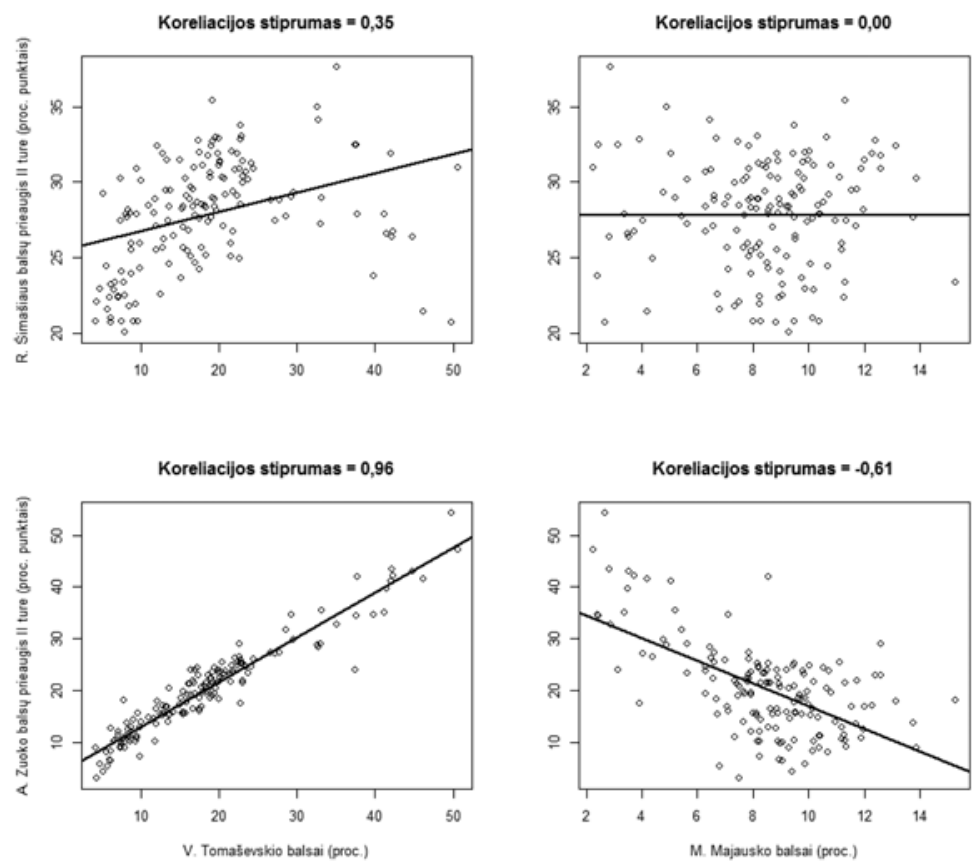

8 pav. R. Šimašiaus ir A. Zuoko balsų prieaugis

\section{Išvados}

Šiame straipsnyje, naudojant reprezentatyvios po $2012 \mathrm{~m}$. rinkimų atliktos apklausos ir 2011 ir 2015 m. savivaldos rinkimų Vilniuje rezultatų duomenis, buvo bandoma sociologiniu požiūriu (tiriant elektoratą) kategorizuoti A. Zuoką ir jo vadovaujamus sąrašus Lietuvos partijų konkurencinejje erdveje. Išskirtos trys hipotezès, kurių kiekviena skirtingu būdu konceptualizuoja literatūroje aprašomą ir pagal A. Zuoko politinę karjerą natūraliai formuluojamą teiginị, jog 
šio politiko profilis yra daugiau centro dešinysis. Statistiniais metodais (koreliacijų, vidurkių patikimumo intervalų ir daugiamačių skalių analizès) tikrinta, ar Zuoko rèmèjai pagal objektyvius kriterijus (1 hipotezè) ir subjektyvias pažiūras i partijas (2 hipotezè), taip pat pagal balsavimo tendencijas Vilniaus apylinkèse (3 hipotezė) yra artimesni dešiniesiems negu lietuviškajai (Vilniaus) centro kairei.

Empirinė analizè suteikia paramos hipotezėms ir leidžia formuluoti išvadą, kad A. Zuokas sociologiškai yra daugiau centro dešinysis politikas. Po $2012 \mathrm{~m}$. rinkimų atliktos apklausos kiekybinè analizè rodo, kad pagal vertybes ir aktualius sociodemografinius kriterijus A. Zuoko potencialus elektoratas turi daugiau panašumo su TS-LKD ir LRLS ir jų lyderiais, negu su socialdemokratais ar tuo labiau DP ir TT. Rinkejjų simpatijų koreliacijos taip pat atskleidžia nors ir ne tobulą, vis dèlto didesni panašumą su dešiniaisiais. Galiausiai, statistinè Vilniaus apylinkių analizè parodo, kad $2011 \mathrm{~m}$. A. Zuoko rinkèjai koncentravosi ten, kur ir konservatorių rinkejjai, o ten, kur geriau sekèsi LLRA ir DP, buvusio sostinès mero rinkèjų buvo mažiau. Panašiai balsuota ir $2015 \mathrm{~m}$. pirmajame ture: vis dèlto tiesioginių mero rinkimų antrojo turo tendencijos atskleide, kad likus dviem kandidatams, Vilniaus kairè (LLRA rinkèjai) labiau parèmé A. Zuoką. Tačiau tai rodo ne tiek kairijji A. Zuoko profilị, kiek tai, kad jis konkurencineje erdvejje yra kiek daugiau pasislinkęs i centrą negu LRLS lyderis R. Šimašius.

Straipsnyje pateiktas tyrimas turi svarbių empirinių ir teorinių implikacijų. Pirma, analizè rodo, kad daugiamačių skalių metodą galima pritaikyti ne tik tiriant individo lygmens apklausas, bet ir nustatant politini konkurencijos lauką pagal realius rinkimų rezultatus apylinkėse. Antra, pateiktas tyrimas gali būti pavyzdys ateities studijoms, besikoncentruojančioms ties konkretaus politiko ar partijos kategorizavimu. Trečia, pirmųjų tiesioginių Vilniaus mero rinkimų analizė rodo, kad profilio pakeitimas, bandymas iš dešinès pasislinkti $\mathfrak{i}$ kairę (ar bent jau gauti iš ten reikšmingos paramos) yra gana sudè- 
tingas dalykas, sunkiai igyvendinamas net ir tokiems viešųjų ryšių meistrams, kaip buvęs sostinès meras. Bandymas „vilioti“ tautinių mažumų elektoratą dabartinèje geopolitinèje situacijoje, tikètina, A. Zuokui kainavo mero postą ar bent jau realią galimybę dèl jo pasivaržyti antrajame ture - dauguma lietuvių rinkèjų susibūrè ties LRLS ir R. Šimašiaus vèliava ir LLRA elektorato parama nesugebejo garantuoti A. Zuokui perrinkimo.

Straipsnyje vartojamu Lietuvos partiju pavadinimu santrumpu sarašas

LICS - Liberalų ir centro sąunga

LLRA - Lietuvos lenkų rinkimų akcija

LLS (liberalai) - Lietuvos laisvès sąunga (liberalai)

LRLS - Lietuvos Respublikos liberalų sąjūdis

LSDP - Lietuvos socialdemokratų partija

RA - Rusų aljansas

TS-LKD - Tèvynès sąjunga-Lietuvos krikščionys demokratai

TT - partija „Tvarka ir teisingumas“ 


\title{
THE POSITION OF ARTŪRAS ZUOKAS IN THE FIELD OF LITHUANIAN POLITICAL COMPETITION: SOCIOLOGICAL ANALYSIS
}

\author{
MAŽVYDAS JASTRAMSKIS
}

\section{Summary}

Keywords: Artūras Zuokas; electorate; field of political competition; electoral district; Vilnius; 2015 local elections.

Discussions about the electoral behaviour are very common in the Lithuanian public sphere. However, there is a lack of academic articles that would focus on the electorates of particular parties or politicians and would employ quantitative analysis. The context of first direct mayoral elections in Lithuania (March 2015) that coincided with the electoral defeat of long-term Vilnius mayor Artūras Zuokas provides a perfect opportunity to analyze the social support base of this politician.
This article employs data from representative survey and uses quantitative methods for the analysis of Artūras Zuokas position in the field of Lithuanian national political competition. Three subsets of analysis are discerned in the article: objective individual, subjective individual and voting in the territorial electoral districts. Empirical analysis suggests that the sociological profile of former Vilnius mayor is center-right, similar to the liberals and conservatives.

Iteikta 2015 m. gegužés $6 \mathrm{~d}$. 